\title{
EGÉSZSÉGES TÁPLÁLKOZÁS VIZSGÁLATA A POSZTADOLESZCENSEK KÖRÉBEN SZOCIOLÓGIAI TÉNYEZÓKKEL KIEGÉSZÍTVE
}

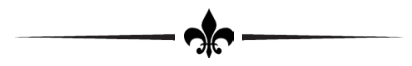

\author{
INVESTIGATION OF HEALTHY NUTRITION IN POST-ADOLESCENTS \\ COMPLEMENTED WITH A SOCIOLOGICAL ASPECTS
}

\author{
$-2$ \\ ${ }^{1}$ KOROKNAY, ZSUZSA \\ ${ }^{1}$ PFAU, CHRISTA \\ ${ }^{2}$ KOVÁCS, SÁNDOR \\ $-10$ \\ ${ }^{1}$ Debreceni Egyetem, Gazdaságtudományi Kar, Sportgazdasági és -menedzsment Intézet \\ (University of Debrecen, Faculty of Economics and Business, Institute of Sports Management) \\ H-4032 Debrecen, Böszörményi út 138. \\ e-mail: koroknay.zsuzsa@econ.unideb.hu \\ ${ }^{2}$ Debreceni Egyetem, Gazdaságtudományi Kar, Statisztika és Módszertani Intézet \\ (University of Debrecen, Faculty of Economics and Business, Institute of Statistics and Research Methodology)
}

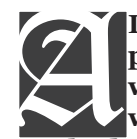

In our rapidly evolving world, a healthy lifestyle has got more and more attention. The prevention and gradual development can never be begun early enough. In our research, we examined the healthy, moderate eating habits of post-adolescents complemented with sociological aspects. We performed primary and secondary data collection. We used methods like descriptive statistics, cross-tabulation analysis, factor analysis, and cluster analysis. In terms of sociologic factors, we examined some dimensions of detachment, which confirmed that university citizens are one group of post-adolescents. The healthy eating habits were analysed by food groups and social factors. During the cluster analysis, we separated 5 clusters and evaluated them by the factors. Based on the factor and cluster analyses, we found that university students consider healthy eating to be an important social value.

KuLCSSZAVAK: posztadoleszcens, táplálkozás, társadalmi érték

JEL-KóDOK (JEL CODES): A13, I12

DOI: https://doi.org/10.20494/TM/8/1/4

\section{BEVEZETÉS - INTRODUCTION}

Egyre nagyobb ütemben fejlődő világunkban számos társadalmi változás figyelhető meg. $\mathrm{Az}$ egészség és egészséges életmód az elmúlt időszakban kiemelt figyelmet kap az emberek életében. A posztadoleszcens életszakaszban lévő fiatalokon belül az egyetemi hallgatókat vizsgáltuk. A fiatal felnőttekkel kapcsolatos
KEYWORDS: post-adolescent, nutrition, social value

vizsgálatokban az egyetemisták önálló almintaként jelennek meg, elkülönítve a hasonló demográfiai jegyeket hordozó, munkát vállaló fiataloktól (KERESZTES et al., 2014). Kutatásunk során egészségfejlesztéssel kapcsolatos megfigyeléseink voltak, kiemelten vizsgálva a posztadoleszcensek táplálkozási szokásait a Debreceni Egyetemen. 


\subsection{Posztadoleszcensek - Post-adolescents}

A szociológia szakirodalmában az elmúlt évtizedben számos utalást találunk egy új társadalmi réteg megjelenésére. $\mathrm{Ez}$ a réteg kor szempontjából a fiatalkor és felnőttkor közé ékelődött be (MEDGYESI és NAGY, 2014). Ezt a korcsoportot nevezzük fiatal felnőtteknek, vagyis posztadoleszcenseknek. Erre az időszakra jellemző, hogy a fiatalkor és felnőttkor jegyeit keverten tartalmazza, valamint a szülői háztartásról való leválás, önállósodás lassan és fokozatosan valósul meg (ANDORKA, 2006). A posztadoleszcens életszakaszban lévő fiatalok többsége bizonyos felnőtté válási jegyeket hordoz magán (mint például a pénz kezelése, partnerválasztás és szexuális kapcsolatok során történő önrendelkezés), azonban bizonyos szociológiai követelményeknek nem teljesen tesznek eleget. Ezen túlmenően ezek a fiatalok a nagykorúság után is anyagi függőségben vannak a szüleikkel (VASKOVICS, 2014). Általánosságban elmondható, hogy ezen fiatal felnőttek bizonyos mértékben függetlenek a szüleiktől, azonban bizonyos fokú függőség is fennáll (TERCZA, 2010).

A társadalmi változások nemcsak egy új társadalmi csoportot hozott létre, hanem hatott az együttélési formák mintájára és megítélésre, a gyermekvállalás idejére és helyzetére, családi szerepekre. Ezek mellett a fiatalok lassú elválása is megfigyelhető a családtól (NEULINGER és MITEV, 2017). Mindez egyrészt a már korábban említett családi helyzethez kapcsolódóan jelenik meg, valamint a kitolódott képzési idővel és gazdasági helyzettel együttesen is hatást gyakorol a leválási folyamatra. VASKOVICS (2000) írásában 5 leválási dimenziót határoz meg: jogi értelemben vett leválás, közös fedél alól történő leválás, anyagi/pénzügyi leválás, önálló döntést eredményező leválás, valamint szubjektív leválási forma vagy öntudatosulás. Azonban az, hogy valakit felnőttnek tekintenek-e vagy sem nemcsak a leválási dimenziók teljesülésétől függ. MURINKÓ (2010) kutatásában megállapításra került, hogy a felnőttséget - a teljes népesség vizsgálatában - egyfajta pszichológiai érettséggel, tanulmányok befejezésével, teljes munkaidős állás betöltésével, a szülőktől való anyagi függetlenséggel, valamint a 18. életév betöltésével azonosítják.
Ugyanezen tényezók egy része figyelhető meg MEDGYESI és NAGY (2014) írásában is, ahol fontos szocio-demográfiai tényezóként jelent meg az életkor, nem, iskolai végzettség és munkaerő-piaci státusz.

A fiatalok, 18-29 év közöttiek a szülői háztól való leválás, illetve az anyagi függetlenség esetében összetettebb értelmezésben figyelhető meg, hiszen nem feltétlenül a családalapításhoz kapcsolódik, hanem az önállóvá válással azonosítják. (MURINKÓ, 2010; ARNOLD, 2011). A posztadoleszcenseken belül, egy szükebb csoportot vizsgáltunk, akik jelenleg felsőoktatási képzésben vesznek részt a Debreceni Egyetemen. Ezen csoport esetében, számos korábban említett ismertető jegy megjelenik, amelyek egyértelmúsítik ezen rétegbe való tagozódásukat. Kutatásunkban a felnőtté válási jegyeken túl a leválás egy-egy dimenzióját vizsgáltuk meg.

A fiatal felnőttek csoportosításával NEULINGER és MITEV (2017) is foglalkozott. A tanulmány nem tér ki a nem otthon élő fiatal felnőttekre, így őket összességében egy csoportnak tekinthetik. Azonban az otthon élő fiatal felnőtteket csoportokra, majd alcsoportokra bontja (1. ábra). A két nagy csoport a csak otthon élők és visszaköltözők. Előbbi esetében azon fiatalokat tekintjük a csoportba tartozónak, akik sosem hagyták még el a szülői házat, nem éltek még külön a családjuktól. A visszaköltözők csoport azokat a fiatal felnőtteket takarja, akik korábban már elhagyták a családjukat és önállóan éltek, azonban valamilyen ok miatt visszaköltöztek szüleikhez (NEULINGER és MITEV, 2017). Ezen fiatal felnőttek csoportra a bumeráng kifejezéssel is találhatóak utalások (BURN és SZOEKE, 2016).

A NEETS egy angol mozaik szó, amely a „Not in Employment, Education or Training” kifejezést takarja. Ebbe a csoportba azon fiatal felnőttek tartoznak, akik szüleikkel együtt élnek, azonban se nem dolgoznak, se nem vesznek részt képzésben (MASCHERINI et al., 2012). A fejlettebb országokban is találni olyan fiatalokat - közel 30-40\% arányban - akik ebbe a kategóriába tartoznak (SOMLAI, 2007). 


\section{Otthon élő fiatal felnőttek (Young adults living at home)}

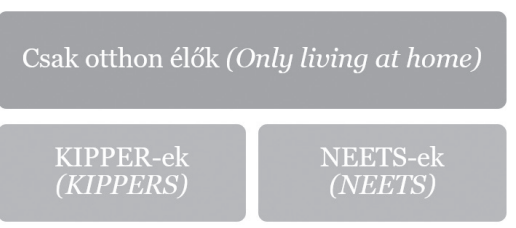

Visszaköltözők

(Moving back)

1. ÁBRA

FIG. 1

Otthon élő fiatal felnőttek csoportosítása (Grouping of Young Adults Living at Home)

Forrás (Source): Saját szerkesztés NEULINGER és MITEV (2017) alapján (Authors' own compilation based on NEULINGER and MITEV (2017))

\subsection{Egészségtudatosság a fiatal felnőttek esetében - Health Awareness of Young Adults}

Napjainkban az egészségszociológiával foglalkozó kutatások száma folyamatosan emelkedik. A lakosság körében elterjedt népbetegségek (többek között elhízás, túlsúly, cukorbetegség) kiemelt fontosságú társadalmi visszacsatolások, hiszen megmutatja, hogy a lakosság egészségügyi helyzete nem megfelelő, továbbá gazdasági terhei is vannak (ÁCS et al., 2011; MAHONEY, 2015; NEFI, 2015; ELEF, 2018; KSH, 2018; T. NAGY-PETÓ et al., 2020). Az elmúlt néhány évtizedben az egészségügyi szociológia egyre nagyobb figyelmet szentel az egészségnek és egészséges magatartásnak (WEISS és LONNQUIST, 2015). A modern egészségügyi szociológiának három ága van (PIKÓ, 2002): egészségügy szociológia, gyógyítás szociológia és egészségszociológia. Előbbi kettő esetében az egyének gyógyításával és gyógyítás körülményeivel foglalkoznak, míg az egészségszociológia esetében a prevenció a mérvadó. Az egészségszociológia számos területtel foglalkozik, mint például milyen feltételek mentén nevezünk valakit betegnek, betegség tapasztalása, az orvosi szakma szervezeti felépítése, kórházak múködése (WHITE, 2002). Ezen kutatási terület foglalkozik az életmód (alvás, táplálkozás, testmozgás és káros szenvedélyek) egészségre gyakorolt befolyásával, ami egyben a betegségekre való hajlandóságot is befolyásolja (COHN, 2014). Tehát az ezzel a témával foglalkozó kutatók az egészség és betegség vizsgálatakor nem mint egészségügyi szakemberek, hanem mint társadalommal foglalkozó kutatók érdekeltek (WHITE, 2002). Az egészség és az egészségtudatos magatartás egy összetett fogalom. Az egészségtudatos magatartás egy sajátos megnyilvánulása az emberi életvitelnek (FODOR, 2013). Az egészségmagatartásnak nyolc alkotóelemét különböztethetjük meg (SZAKÁLY, 2008; DUDÁS, 2015). A nyolc alkotóelem közé tartozik a káros szenvedélyektől való mentesség, egészséges, mértékletes táplálkozás, rendszeres testmozgás, lelki egészségről való gondoskodás, nyugodt élet, stressz kerülése, egészséges szexualitás, szűrővizsgálatokon való rendszeres megjelenés, védőoltások, táplálékkiegészítők, vitaminok fogyasztása, betegségek kezelése (DUDÁS, 2011). Kutatásunk során az egészségszociológia azon részét vizsgáltuk, hogy az egészséges életmód egyik alkotóeleme, azaz a táplálkozás hogyan alakul a posztadoleszcensek körében.

Mindezen szociológiai jellemzők és társadalmi hatások befolyásolják a posztadoleszcens életszakaszban lévő fiatalok élelmiszer választását (SHARMA et al. 2010). Kutatások támasztották alá, hogy ha fiatal felnőttkorban kialakul egészségtelen élelmiszerválasztási mintázat, akkor nagy valószínűséggel életük végéig fennmarad (SHARMA et al., 2010; FITZGERALD et al., 2013). A fiatalok esetében megfigyelhető, hogy nagymértékben fogyasztanak zsírban, cukorban és sóban gazdag ételeket, míg zöldség, gyümölcs, teljes kiőrlésű gabonafélék és kálciumban gazdag ételek fogyasztása alacsony (FITZGERALD et al., 2013). A leggyakrabban alkalmazott elmélet a Socio-Cognitive Theory (továbbiakban: SCT), amely egyfajta beavatkozás a fiatalok egészsé- 
ges táplálkozásának elősegítésébe. Ezen elmélet hangsúlyozza a személyes, szocio-környezeti és viselkedési faktorokat, amelyek nemcsak egymásra vannak befolyással, hanem az egészséges táplálkozásra is (CERIN et al., 2009). Az egymásra való hatás példájaként említhető, hogy a szocio-környezeti tényezők, mint például a társadalmi támogatás képes befolyásolni direkt vagy indirekt módon a személyes faktort (FITZGERALD et al., 2013).

SHARMA et al. (2010) tanulmányában számos kutatást összegezve megállapította, hogy az emberek élelmiszer választását számos tényező befolyásolja, melyek közül kiemelkedik az egészség, ár, kényelem és az íz. Az áttekintett tanulmányok egy multidimenziós motivációs mérést határoztak meg az élelmiszerválasztásra vonatkozóan, melynek keretében kilenc faktort azonosítottak. A kilenc faktor közé tartozik szintén az egészség, ár, kényelem, azonban ezeken felül az életmód, vonzerő, természetes tartalom, súlykontroll, ismertség és etikai kérdések is megjelennek (SHARMA et al. 2010). Ezen tényezőkön felül a fiatal felnőttkorban lévő egyetemisták esetében megfigyelhető, hogy egy részük fogyasztási választásukat saját családjukban tapasztaltak alapján hozzák meg, azonban már elkezdenek önálló és független élelmiszerválasztási döntéseket hozni (PLATANIA et al., 2016).

\section{ANYAg És Módszer - MATERIAL AND METHOD}

A kutatás során az volt a célunk, hogy meghatározzuk a posztadoleszcens életkorban lévő egyetemi polgárság táplálkozási szokásait és befolyásoló tényezőit. Primer és szekunder adatokat gyüjtöttünk. Szekunder adatgyüjtés során szakirodalmi forrásokat tekintettünk át a téma átfogó bemutatása érdekében. Primer adatgyüjtés esetében kérdőíves megkérdezést alkalmaztunk online és papír alapon egyaránt. A kérdőív összeállítása során három korábbi kérdőívet vettünk alapul, melyek az egészséges életmóddal foglalkoznak, azon belül is a táplálkozásra helyezik a hangsúlyt. Kérdőívünkben a szociológiai aspektusokra vonatkozó kérdéseket és állításokat BALATONI (2011) és SZABÓ (2016) doktori disszertációja alapján fogalmaz- tuk meg, míg a táplálkozási szokások esetében az élelmiszercsoportok meghatározásakor EL ANSARI et al. (2015) tanulmányában található csoportosítást vettük át és egészítettük ki MAGYAR IFJÚSÁG KUTATÁS (2016) néhány elemével.

A kérdőíves megkérdezésben 572 hallgató vett részt. Az adatok átnézése és tisztítása során 12 kérdőív esetében előfordult, hogy több mint 4 helyen hiányzott egyszerre adat, ezért ezeket a kérdőíveket nem vettük figyelembe. Ennek következtében a mintába 560 elem került be és a fenti hiányzó érték arányokat (mintegy 5\% alatti minden esetben) az átlaggal pótoltuk a fókomponens elemzés elvégzéséhez. Az 560 fő nem szerinti megoszlásáról elmondható, hogy a mintában résztvevők 43,8\%-a férfi, míg 56,3\%-a nő volt. A válaszadók 42\%-a városban, 35,9\%-a megyei jogú városban él, a fennmaradó százalék pedig kisebb településen. Képzési szintet figyelembe véve a megkérdezettek döntő hányada, 88,8\%-a alapképzésben tanul a Debreceni Egyetemen, a fennmaradó százalékban pedig FOSZ, mester, osztatlan és PhD hallgatók találhatóak.

Számításainkat az IBM SPSS Statistics 22 és $\mathrm{R}$ 3.4.4. statisztikai szoftverrel végeztük el (R CORE TEAM, 2019). A leíró statisztikai számításokat az SPSS programon keresztül, míg a további statisztikai módszereket az R 3.4.4. statisztikai szoftveren futtattuk le. A hiányzó adatok kezelésére a MICE (Multivariate Imputation by Chained Equations) csomagot használtuk, a főkomponens elemzés elvégzésére a psych csomag principal függvényét, míg a Kaiser-Meier-Oldin (KMO) teszthez a KMO függvényt alkalmaztuk. A KMO teszt a legfontosabb mutató a fókomponenselemzés alkalmasságának eldöntésére. Értékének legalább o,6-nak kell lennie és az adatok korrelációjának erősségével függ össze. A klaszterelemzés elvégzéséhez a Hierarchikus klaszterezést (Ward módszer szerinti) választottuk ki több módszer közül és több csoportosítást végeztünk, amelyből az 5 klaszteres megoldást választottuk. A módszereket, illetve a kapott klasztereket a Dunn (CHEN et al., 2002; MACKAY, 2006), C-index (HUBERT és SCHULTZ, 1976) klaszterminőség mérő mértékekkel hasonlítottuk össze (clusterCrit csomag).

Mivel a változóink 5 fokozatú Likert skálán 
mért, ordinális típusúak voltak, ezért a főkomponens elemzést a Spearman-féle rangkorrelációs mátrixon keresztül futtattuk a Pearson-féle korrelációs mátrix helyett. Minden válaszadó esetén képeztünk egy-egy fókomponens értéket az ún. súlyok és az állításokra adott értékek használatával. Az így keletkezett főkomponens átlagértéke 0 és +1 és -1 között vehet fel értékeket attól függően, hogy a fókomponenshez tartozó állítások milyen súllyal szerepelnek a fókomponensben, és milyen értékelést kaptak. A fókomponensekhez minden esetben pozitív súllyal tartozó állítások a főkomponens értékét növelték, ha ezeket az átlagosnál relatíve fontosabbnak ítélték a válaszadók és a főkomponens értékét csökkentették, ha ezekre az átlagnál relatíve alacsonyabb értékkel válaszoltak a megkérdezettek. A fókomponensek használatával szemléletesebben értékelhető, hogy a válaszadók mely állításokat tartottak relatíve fontosabbnak, illetve mely élelmiszercsoportokból fogyasztanak relatíve többet/kevesebbet, és nem kellett az eredetileg számos állítást, élelmiszert egyszerre bemutatni. A keletkezett fókomponens értékek különbözőségeit az egyes klaszterekben varianciaelemzéssel vizsgáltuk. A varianciaelemzés minden esetben különbséget tárt fel a főkomponensek értékében a kialakított klaszterekben.

\section{EREDMÉNYEK - RESUlts}

\subsection{Szociológiai aspektus - Sociological Aspect}

$\mathrm{Az}$ egyetemi hallgatókat a posztadoleszcens életszakaszra jellemző jegyek mentén is megvizsgáltuk. Az ismertető jegyek közül a jogi értelemben vett leválást, a közös fedél alól történő leválást, valamint a pénzügyi függőséget vizsgáltuk meg. VASKOVICS (2000) írásában a jogi értelemben vett leválás alatt a kor szerinti nagykorúság elérését érti, melyben a cselekvő személy korlátozás nélkül hozhat jogi érvényességü nyilatkozatot. Tehát ebben az esetben a megkérdezettek életkorát szükséges megvizsgálni. A gyakorisági adatok alapján a megkérdezettek döntő többsége $(98,9 \%)$ 1827 év közötti, de a mintába bekerült hallgatók mindegyike betöltötte a 18. életévét, ezáltal a jogi értelemben vett leválás minden esetben teljesül. A mintába bekerültek átlagos életkora 20,24 év (szórás: 3,173).

A második vizsgált szociológiai aspektus a közös fedél alól történő leválás, amely alatt a szülői háztól való elköltözést értjük (VASKOVICS, 2000) (1. táblázat). A kérdőívben arra a kérdésre, hogy egyetemi éveik alatt hol élnek, több lehetőség közül is választhattak: saját tulajdonú ingatlanban családdal, saját tulajdonú ingatlanban egyedül, kollégiumban, albérletben családdal/barátokkal/ismerősökkel, albérletben egyedül, bejárós. A leválás egyértelmüen látható a saját tulajdonú ingatlanban (7\%), illetve albérletben egyedül $(3,6 \%)$ élők esetében. A leválás nem figyelhető meg a saját tulajdonú ingatlanban családdal $(28,4 \%)$ és a bejárós vagyok $(9,6 \%)$ választ adók esetében. Részben figyelhető meg leválás a kollégisták esetében (28,2\%). Nem egyértelmüsíthető az albérletben családdal/barátokkal/ismerősökkel válaszadók leválása, ám feltételezhető egy részbeni elszakadás a családtól.

A harmadik vizsgált jellemző a pénzügyi függőség-függetlenség. A kérdőíves megkérdezés során két kérdéssel kívántuk felmérni a hallgatók pénzügyi függőségét a családtól. A megkérdezettek pénzügyi függőségét kereszttáblás elemzés segítségével vizsgáltuk meg (1. táblázat).

A pénzügyi leválás két változójáról elmondható, hogy a Khi négyzet teszt, Pearson Chi-Square értékének szignifikancia szintje o,oo, azaz a két változó között kapcsolat áll fent. A változók kapcsolódási pontjait az Adjusted Residual sor értékei mutatják meg. A saját magukat eltartók körében átlagon felüli arányban vannak azok, akik rendszeresen dolgoznak, azonban szignifikáns mértékben átlag alatti a nem dolgozók körében. Azok a megkérdezettek, akik részben tartják el magukat döntő többségben rendszeresen vagy szünidőben dolgoznak. Az utolsó állítás esetében pedig egyértelműen megfigyelhető, hogy a nem dolgozó fiatalok felülreprezentáltak. 
Koroknay, Zs. - Pfau, C. - Kovács, S.

Anyagi leválás vizsgálata (Examination of Material Detachment)

\begin{tabular}{|c|c|c|c|c|c|c|}
\hline & & & \multicolumn{3}{|c|}{$\begin{array}{l}\text { Dolgozik-e tanulmányai alatt? (Do } \\
\text { you work during your studies?) }\end{array}$} & \multirow[b]{2}{*}{$\begin{array}{l}\text { Össze- } \\
\text { sen } \\
\text { (Total) }\end{array}$} \\
\hline & & & $\begin{array}{l}\text { Igen, rend- } \\
\text { szeresen } \\
\text { (Yes, } \\
\text { regularly) }\end{array}$ & $\begin{array}{l}\text { Igen, } \\
\text { szünidő- } \\
\text { ben } \\
\text { (Yes, in } \\
\text { summer } \\
\text { holidays) }\end{array}$ & $\begin{array}{l}\text { Nem } \\
\text { (No) }\end{array}$ & \\
\hline \multirow{15}{*}{ 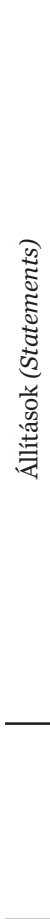 } & \multirow{4}{*}{$\begin{array}{l}\text { Saját magamat tartom el } \\
\text { az egyetemi évek alatt. ( } \\
\text { support myself during } \\
\text { my university years.) }\end{array}$} & Számítás (Count) & 18 & 6 & 4 & 28 \\
\hline & & $\begin{array}{l}\text { Soronkénti megoszlás (within } \\
\text { Statements) (\%) }\end{array}$ & 64,3 & 21,4 & 14,3 & 100,0 \\
\hline & & $\begin{array}{l}\text { Oszloponkénti megoszlás (within } \\
\text { Work) (\%) }\end{array}$ & 15,7 & 3,1 & 1,6 & 5,0 \\
\hline & & Adjusted Residual & 5,9 & $-1,5$ & $-3,3$ & \\
\hline & \multirow{4}{*}{$\begin{array}{l}\text { Részben magamat tar- } \\
\text { tom el, de kapok anyagi } \\
\text { támogatást otthonról. (I } \\
\text { support myself in part, } \\
\text { but I get financial sup- } \\
\text { port from my family.) }\end{array}$} & Számítás (Count) & 75 & 95 & 57 & 227 \\
\hline & & $\begin{array}{l}\text { Soronkénti megoszlás (within } \\
\text { Statements) (\%) }\end{array}$ & 33,0 & 41,9 & 25,1 & 100,0 \\
\hline & & $\begin{array}{l}\text { Oszloponkénti megoszlás (within } \\
\text { Work) (\%) }\end{array}$ & 65,2 & 48,5 & 22,9 & $40,5 \%$ \\
\hline & & Adjusted Residual & 6,0 & 2,8 & $-7,6$ & \\
\hline & \multirow{4}{*}{$\begin{array}{l}\text { Nem tartom el maga- } \\
\text { mat, a családom segít } \\
\text { anyagilag. (I do not } \\
\text { support myself, my } \\
\text { family supports me.) }\end{array}$} & Számítás (Count) & 22 & 95 & 188 & 305 \\
\hline & & $\begin{array}{l}\text { Soronkénti megoszlás (within } \\
\text { Statements) (\%) }\end{array}$ & 7,2 & 31,1 & 61,6 & 100,0 \\
\hline & & $\begin{array}{l}\text { Oszloponkénti megoszlás (within } \\
\text { Work) (\%) }\end{array}$ & 19,1 & 48,5 & 75,5 & 54,5 \\
\hline & & Adjusted Residual & $-8,5$ & $-2,1$ & 8,9 & \\
\hline & \multirow{3}{*}{ Összesen (Total) } & Számítás (Count) & 115 & 196 & 249 & 560 \\
\hline & & $\begin{array}{l}\text { soronkénti megoszlás (within } \\
\text { Statements) (\%) }\end{array}$ & 20,5 & 35,0 & 44,5 & 100,0 \\
\hline & & $\begin{array}{l}\text { Oszloponkénti megoszlás (within } \\
\text { Work) (\%) }\end{array}$ & 100,0 & 100,0 & 100,0 & 100,0 \\
\hline
\end{tabular}

Forrás (Source): Saját szerkesztés (Authors'own compilation) 


\subsection{Egészséges táplálkozás vizsgálata -} Examination of Healthy Eating

Vizsgálatunk során az egyetemi hallgatóság táplálkozási szokásait élelmiszercsoportok mentén mértük fel, melynek alapjául EL ANSARI et al. (2015) és MAGYAR IFJÚSÁG KUTATÁS (2016) tanulmányokat vettük. A válaszadók fogyasztási gyakoriságokat (Naponta többször, Naponta egyszer, Hetente többször, Havonta 1-4 alkalommal, Soha) jelöltek meg a következő élelmiszercsoportokra vonatkozóan: Édesség, Nasi, Fast food, Friss gyümölcs, Zöldségek, Húsok, Halak és tenger gyümölcsei, Gabonafélék, Tej, tejtermékek, Tojás, Limonádé, cukrozott üdítőital, Cukormentes üdítőital, Energiaital, Kávé.

A 2. táblázat megmutatja a fogyasztási gyakoriságokat százalékos bontásban élelmiszercsoportok szerint. A húsok esetében figyelhető meg a legnagyobb mértékủ napi szintű fogyasztás (71,25\%). Az egészségesebb élelmiszercsoportok (zöldség, gyümölcs, gabona, tejtermékek és tojás) fogyasztására a megkérdezettek körében jellemző a hetente többször vagy annál gyakrabbi fogyasztás. A halfogyasztás azonban nem jellemző a megkérdezettekre, hiszen inkább havi 1-4 alkalommal vagy egyáltalán nem esznek halat. A Nasira és Fast foodra a havi 1-4 alkalom, míg az édességre a hetente többszöri vagy akár napi szintű fogyasztás a jellemző. A legtöbben havi 1-4 alkalommal vagy hetente többször fogyasztanak cukros és cukormentes üdítőket. A kávét és energiaitalt soha nem használók vannak a legnagyobb hányadban, azonban ez csekély mértékü a használókkal szemben. Kávét a legtöbben naponta legalább egyszer $(38,58 \%)$, energiaitalt pedig hetente legalább egyszer (46,61\%) fogyasztanak.

2. TÁBLÁZAT

TABLE 2

Fogyasztási szokások élelmiszercsoportok szerint, \% (Consumption Habits by Food Groups, \%)

\begin{tabular}{lccccc}
\hline Élelmiszercsoportok (Food groups) & $\begin{array}{c}\text { Soha } \\
\text { (Never) }\end{array}$ & $\begin{array}{c}\text { Havonta 1-4 } \\
\text { alkalommal } \\
\text { (1-4 times } \\
\text { per month) }\end{array}$ & $\begin{array}{c}\text { Hetente } \\
\text { többször } \\
\text { (Several } \\
\text { times per } \\
\text { week) }\end{array}$ & $\begin{array}{c}\text { Naponta } \\
\text { egyszer } \\
\text { (Daily) }\end{array}$ & $\begin{array}{c}\text { Naponta } \\
\text { többször } \\
\text { (Several } \\
\text { times per } \\
\text { day) }\end{array}$ \\
\hline Édesség (Sweets) & 2,14 & 31,79 & 36,25 & 20,00 & 9,82 \\
\hline Nasi (Snacks) & 3,93 & 47,86 & 35,54 & 8,39 & 4,29 \\
\hline Fast food & 5,54 & 67,86 & 23,57 & 1,96 & 1,07 \\
\hline Gyümölcs (Fruits) & 1,07 & 14,46 & 46,96 & 20,36 & 17,14 \\
\hline Zöldség (Vegetables) & 2,14 & 10,00 & 45,18 & 22,50 & 20,18 \\
\hline Húsok (Meats) & 1,61 & 1,96 & 25,18 & 31,61 & 39,64 \\
\hline Halak (Fish) & 23,04 & 50,36 & 18,21 & 5,36 & 3,04 \\
\hline Gabona (Cereals) & 3,39 & 18,04 & 27,14 & 27,86 & 23,57 \\
\hline Tejtermék (Dairy products) & 4,29 & 8,21 & 30,54 & 32,86 & 24,11 \\
\hline Tojás (Egg) & 2,50 & 16,61 & 53,93 & 18,57 & 8,39 \\
\hline Cukros üdítő (Soft drinks) & 15,18 & 35,54 & 26,79 & 11,79 & 10,71 \\
\hline Cukormentes üdító (Sugar-free soft drink) & 23,75 & 29,46 & 21,07 & 10,36 & 15,36 \\
\hline Energiaital (Energy drink) & 36,25 & 28,75 & 17,86 & 11,43 & 5,71 \\
\hline Kávé (Coffee) & 25,18 & 15,00 & 21,25 & 16,79 & 21,79 \\
\hline (E) & & & & \\
\hline
\end{tabular}

Forrás (Source): Saját szerkesztés (Authors'own compilation) 
A 3. táblázat alapján megállapítható, hogy az egyes élelmiszercsoportok fogyasztási gyakoriságaira 5 fókomponenst tudtunk kialakíta- ni, amely az információ 60\%-át megőrizte, valamint a Kaiser-Meier-Oldkin (KMO) mutató értéke is megfelelő volt $(0,65)$.

3. TÁBLÁZAT

TABLE 3

Az egyes élelmiszercsoportok fogyasztási szokásainak értékelése PCA elemzéssel (Evaluation of Consumption Habits of Each Food Group by PCA Analysis)

\begin{tabular}{|c|c|c|c|c|c|c|}
\hline \multirow[b]{2}{*}{$\begin{array}{l}\text { Élelmiszercsoportok } \\
\text { (Food groups) }\end{array}$} & \multicolumn{5}{|c|}{ Főkomponensek (Principal components) } & \multirow[b]{2}{*}{$\begin{array}{c}\text { Magya- } \\
\text { rázott } \\
\text { variancia } \\
\text { (Explained } \\
\text { variance) } \\
(\%)\end{array}$} \\
\hline & $\begin{array}{l}\text { Nasi, } \\
\text { édesség } \\
\text { (Snacks, } \\
\text { sweets) }\end{array}$ & $\begin{array}{c}\text { Zöldség, } \\
\text { gyümölcs } \\
\text { (Vegetable, } \\
\text { fiuit) }\end{array}$ & $\begin{array}{c}\text { Tej, tojás, } \\
\text { gabona } \\
\text { (Dairy } \\
\text { products, } \\
\text { egg, cereals) }\end{array}$ & $\begin{array}{l}\text { Divatos } \\
\text { termékek } \\
\text { (Fashio- } \\
\text { nable } \\
\text { products) }\end{array}$ & $\begin{array}{l}\text { Hús, hal } \\
\text { (Fish, } \\
\text { meat) }\end{array}$ & \\
\hline Édesség (Sweets) & 0,75 & 0,12 & 0,12 & $-0,14$ & $-0,23$ & 67 \\
\hline Nasi (Snacks) & $\mathbf{0 , 8 4}$ & 0,06 & 0,03 & 0,00 & $-0,02$ & 71 \\
\hline Fast food & 0,65 & $-0,12$ & $-0,04$ & 0,20 & 0,21 & 52 \\
\hline Friss gyümölcs (Fruits) & 0,07 & 0,86 & 0,07 & $-\mathrm{O}, \mathrm{O1}$ & 0,09 & 76 \\
\hline Zöldségek (Vegetables) & $-0,08$ & $\mathbf{0 , 8 6}$ & 0,12 & 0,01 & 0,09 & 78 \\
\hline Húsok (Meats) & 0,01 & 0,15 & 0,38 & 0,04 & $\mathbf{0 , 5 2}$ & 56 \\
\hline Halak (Fish) & $-0,07$ & 0,33 & 0,08 & 0,22 & $\mathbf{0 , 5 1}$ & 57 \\
\hline Gabonafélék (Cereals) & $\mathrm{O}, \mathrm{O} 3$ & 0,13 & 0,68 & $-0,07$ & 0,07 & 51 \\
\hline $\begin{array}{l}\text { Tej, tejtermékek (Dairy } \\
\text { products) }\end{array}$ & 0,08 & $-0,04$ & 0,82 & 0,13 & $-0,10$ & 71 \\
\hline Tojás (Egg) & $-0,03$ & 0,13 & 0,56 & 0,16 & 0,42 & 54 \\
\hline Cukros üdítő (Soft drink) & 0,54 & $-0,25$ & 0,02 & 0,41 & 0,12 & 54 \\
\hline $\begin{array}{l}\text { Cukormentes üdítő } \\
\text { (Sugar-free soft drink) }\end{array}$ & $-0,05$ & 0,06 & 0,15 & 0,62 & 0,17 & 56 \\
\hline Energiaital (Energy drink) & 0,22 & $-0,03$ & $-0,07$ & $\mathbf{0 , 7 8}$ & $-0,14$ & 68 \\
\hline Kávé (Coffee) & $-0,13$ & 0,18 & 0,27 & 0,44 & $-0,63$ & 72 \\
\hline $\begin{array}{l}\text { Magyarázott variancia } \\
\text { (Explained variance) (\%) }\end{array}$ & 15 & 13 & 12 & 11 & 9 & \\
\hline $\begin{array}{l}\text { Kumulált magyarázott vari- } \\
\text { ancia (Cumulated explained } \\
\text { variance) (\%) }\end{array}$ & 15 & 28 & 40 & 51 & 60 & \\
\hline
\end{tabular}

Forrás (Source): Saját szerkesztés (Authors'own compilation)

Megjegyzés (Note): KMO: 0,65

A zöldség, gyümölcs, édesség és nasi, tejtermékek, valamint a kávé és energiaital élelmiszercsoportok esetén sikerült a legtöbb varianciát megmagyarázni a fókomponensekkel. A fókomponensek kialakításakor az értelmezhetőséget és a leginkább korreláló tényezőket vettük figyelembe. Ennek alapján egymástól jól elkülönülten kialakult egy édesség-nasi-fast food, egy zöldség-gyümölcs, egy tej, tejtermékek-tojás-gabonafélék, egy divatos termékek (cukros üdítő, cukormentes üdítő, energiaital és kávé) és egy halak, tenger gyümölcsei-húsok fókomponens.
Az élelmiszercsoportok mellett az egészséges táplálkozás társadalmi megítélést is vizsgáltuk szintén főkomponens elemzés segítségével. Mindezt úgy mértük, hogy a megkérdezettek egy egytől ötig terjedő skálán értékelték, hogy mennyire értenek egyet a megadott állításokkal. Az állítások az egészséges táplálkozást különböző társadalmi aspektusokból közelítették meg.

A 4. táblázat alapján látható, hogy az egészséges táplálkozás társadalmi vonatkozásaira 3 fókomponenst tudtunk kialakítani, amely az információ 65\%-át megőrizte, valamint a 
KMO mutató értéke is megfelelő volt $(0,74)$. A főkomponens elemzés és a kialakított fókomponensek megfelelő voltát mutatja az a tény is, hogy a 3 fókomponens együttesen az egyes itemek varianciájának több, mint 50\%-át megmagyarázta.

TABLE 4 Az egészséges táplálkozás társadalmi vonatkozásainak értékelése PCA elemzéssel (Evaluating the Social Aspects of Healthy Eating by PCA Analysis)

\begin{tabular}{|c|c|c|c|c|}
\hline \multirow[b]{2}{*}{ Állítások (Statements) } & \multicolumn{3}{|c|}{ Főkomponensek (Principal componenst) } & \multirow[b]{2}{*}{$\begin{array}{c}\text { Magyarázott } \\
\text { variancia } \\
\text { (Explained } \\
\text { variance) (\%) }\end{array}$} \\
\hline & $\begin{array}{c}\text { Társadalmi } \\
\text { érték (Social } \\
\text { value) }\end{array}$ & $\begin{array}{c}\text { Rossz } \\
\text { divat (Bad } \\
\text { fashion) }\end{array}$ & $\begin{array}{c}\text { Társas } \\
\text { támasz } \\
\text { (Social } \\
\text { support) }\end{array}$ & \\
\hline Élvezetes (Enjoyable) & 0,64 & $-0,22$ & 0,45 & 66 \\
\hline Ismerősei tesznek érte (Friends do for it) & 0,07 & 0,09 & $\mathbf{0 , 8 8}$ & 80 \\
\hline $\begin{array}{l}\text { Ismerőseinek érték (It's valuable for your } \\
\text { friends) }\end{array}$ & 0,26 & 0,05 & $\mathbf{0 , 7 9}$ & 69 \\
\hline Törekszik rá (Strives for it) & $\mathbf{0}, 7 \mathbf{1}$ & $-0,18$ & 0,35 & 65 \\
\hline Társadalmi érték (Social value) & $\mathbf{0 , 7 2}$ & $-0,14$ & 0,18 & 57 \\
\hline $\begin{array}{l}\text { Fontosabb, mint a sport (More important than } \\
\text { sports) }\end{array}$ & $\mathbf{0}, 7 \mathbf{1}$ & 0,23 & $-0,10$ & 57 \\
\hline $\begin{array}{l}\text { Gazdagok kiváltsága (It's a privilege of the } \\
\text { rich) }\end{array}$ & 0,08 & $\mathbf{0 , 7 5}$ & $-0,04$ & 57 \\
\hline Egyhangú étkezés (Unanimous eating) & $-0,06$ & $\mathbf{0 , 8 0}$ & 0,04 & 65 \\
\hline Újabb divat csupán (Just another fashion) & $-0,20$ & $\mathbf{0 , 8 0}$ & 0,09 & 69 \\
\hline $\begin{array}{l}\text { Magyarázott variancia (Explained variance) } \\
(\%)\end{array}$ & 22,8 & 22,4 & 19,8 & \\
\hline $\begin{array}{l}\text { Kumulált magyarázott variancia (Cumulated } \\
\text { explained variance) (\%) }\end{array}$ & 22,8 & 45,2 & 65,0 & \\
\hline
\end{tabular}

Forrás (Source): Saját szerkesztés (Authors'own compilation)

Megjegyzés (Note): KMO: 0,74

A fókomponensek értelmezésekor az azokkal leginkább korreláló tényezóket vettük figyelembe. Ennek alapján egymástól jól elkülönülten kialakult egy társadalmi érték, egy rossz divat, valamint egy társas támasz fókomponens. Társadalmi érték fókomponens esetében elmondható, hogy az egészséges életmódot élvezetesnek tartják, törekednek arra, hogy ezt az életmódot folytassák. Továbbá fontos társadalmi értéknek tartják az egészséges táplálkozást, ami fontosabb a sportnál. A rossz divat fókomponens esetében egy negatívabb képet kapunk az egészséges táplálkozásról. Ezen főkomponenshez tartoznak azok az állítások, amelyek arra világítanak rá, hogy az egészséges táplálkozás a gazdagok kiváltsága, egy egyhangú étkezési formáról, valamint csak egy újabb divatról van szó. A harmadik főkomponens a társas támasz, ami alatt az ismeretségi kör támogatását értjük, valamint értékkel bír az egészséges táplálkozás.

A 2. ábra mutatja be a társadalmi vonatkozás főkomponens értékeinek alakulását az 5 klaszterben. A klaszterek sorszáma, ahogyan növekszik, úgy csökken a társadalmi értéke az egészséges magatartásnak. Az egészséges magatartásnak a társadalmi értéke az első 3 csoportban a legnagyobb, az utolsó két csoportban egyáltalán nem törekednek, és nem helyezik elótérbe az egészséges életmódot (divatos termékek és halak-húsok). Az első csoportban a társadalmi érték azonban rossz divattal is párosul, azaz az egészséges táplálkozást egy kiváltságos, egyhangú lehetőségként, valamint egy újabb divatnak tartják. A második és harmadik csoport ebben különbözik az elsőtől. A második és harmadik klaszter egymástól a társas támaszban is eltér, ugyanis a 3. csoportban 
az ismerősi befolyás jelentőséggel bír. Ez a fajta társadalmi vonatkozás az első és harmadik csoportban van jelen. Az utolsó csoportban, ahol legkevésbé tartják az egészséges táplálkozást értéknek, nincs meg a társas támasz és divatnak fogják fel az egészet, valamint a gazdagok kiváltságának tartják az egészséges táplálkozást.

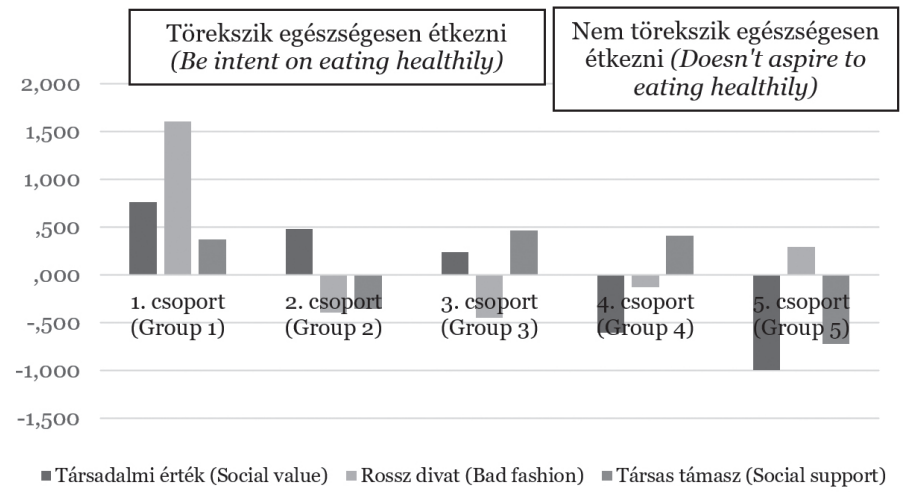

2. ÁBRA

A társadalmi vonatkozás fókomponens értékeinek alakulása az egyes klaszterekben FIG. 2 (Changes in the Values of the Principal Components of Social Relevance in Each Cluster) Forrás (Source): Saját szerkesztés (Authors'own compilation)

A különbség szembeötlő, a három csoportban, ahol társadalmi érték az egészséges táplálkozás és törekszenek rá, ott relatíve gyakrabban fogyasztanak valamelyik egészséges élelmiszercsoportból is. Az 1. csoportban a hal és hústermékek dominálnak, azonban megjelennek mellette a divatos termékek és kismértékben a nasi-édesség. A második csoportban a tojás, tej, gabonatermékek fogyasztása a meghatározó, valamint kismértékủ hús és halfogyasztás látható. A harmadik csoportban a zöldség, gyümölcs fogyasztás nagymértékben megjelenik, ami hús és halfogyasztással párosul. Illetve megjelenik még a nasi, édesség és fast food fogyasztása is. A negyedik és ötödik csoportban, ahol kevésbé törekszenek az egészséges étkezésre, relatíve kevesebbszer fogyasztanak zöldséget, gyümölcsöt, valamint halat és húst. A negyedik csoport esetében elmondható, hogy mindenből viszonylag kevesebbet fogyaszt. A legutolsó klaszterben a nasi, édesség, fast food termékek dominálnak, amely mellett megjelennek a divatos termékek is, azaz a különféle üdítőitalok és energiaital, kávé.

3. ÁBRA

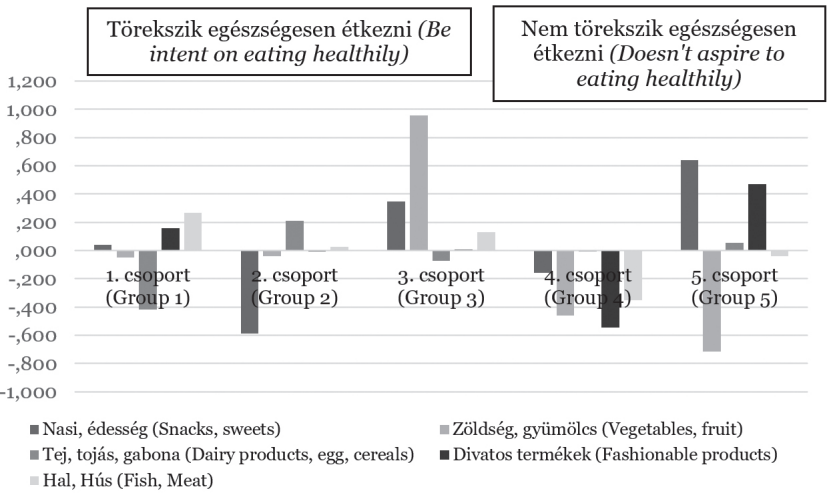

FIG. 3

Élelmiszercsoportok fogyasztásának alakulása az egyes klaszterekben (Consumption of Food Groups in Each Cluster)

Forrás (Source): Saját szerkesztés (Authors'own compilation) 


\section{KöVETKEZTETÉSEK - CONCLUSIONS}

A mai rohanó világban az egészségszociológiának egyre nagyobb jelentősége van, hiszen az egészségre, egészséges életmódra való törekvés trendként jelenik meg a fiatal felnőttek körében. Kutatásunkban a posztadoleszcensek egészséges, mérsékletes táplálkozási szokásait vizsgáltuk meg szociológiai szempontokkal kiegészítve. Kutatás alanyainak azért választottuk őket, mert ebben a korosztályban kialakuló mintázatok nagy valószínűséggel életük végéig megmaradnak.

Szociológiai szempontból több leválási folyamatot is értelmeztünk a mintánk elemzésekor. Jogi szempontból megállapítható, hogy a megkérdezettek mindegyike megfelel a jogi leválás kritériumainak. A közös fedél alól történő leválási folyamat vizsgálatai során három szakaszt figyelhettünk meg: teljes leválás $(10,6 \%)$, részbeni leválás $(28,2 \%)$, nincs leválás (38\%). A fennmaradó százalékban nem egyértelmüsíthető a leválás, mindössze részbeni leválás feltételezhető. A harmadik vizsgált leválási forma a pénzügyi függőség. Ebben az esetben elmondható, hogy a saját magukat eltartók körében átlagon felüli arányban vannak a rendszeresen dolgozók (64,3\%), ám a mintanagysághoz képest alacsony a létszámuk. A részben magukat eltartók rendszeresen vagy szünidőben dolgoznak leginkább; míg a magukat el nem tartók esetében a nem dolgozó fiatalok felülreprezentáltak (61,6\%). Összességében elmondható, hogy a megkérdezésben résztvevő fiatalok döntő hányadánál nem figyelhető meg pénzügyi függetlenség. Ezek alapján megállapítható, hogy az egyetemi polgárság valóban a posztadoleszcensek csoportjába tartozik.

$\mathrm{Az}$ egészséges táplálkozás vizsgálatakor nemcsak az élelmiszercsoportok fogyasztási gyakoriságát vizsgáltuk, hanem egymáshoz való viszonyát is főkomponenselemzés segítségével. Továbbá társadalmi főkomponenseket is alkottunk. Élelmiszercsoportok esetében 5 főkomponenst határoztunk meg: nasi-édesség-fast food, zöldség-gyümölcs, tojás-tej-gabona, divatos termékek (üdítő italok és serkentők), valamint hal-hús. A társadalmi vonatkozást tekintve 3 fókomponens alakult ki: a társadalmi érték, társas támasz, rossz divat. A társadalmi érték a táplálkozást egy élvezetes, fontos és értékkel bíró tevékenységnek írja le. A társas támasz az ismeretségi körben lévő elfogadást és támogatást foglalja magába, míg a rossz divat esetében az egészséges táplálkozás negatív megítélését összegzi. A megkérdezettek öt klaszterbe kerültek besorolásra a kialakított főkomponensek mentén. A társadalmi fókomponensek alapján három klaszterben törekednek egészségük megóvására. Ezen klaszterekben az egészséges táplálkozás, mint társadalmi érték jelenik meg, míg a másik kettőben nem, és nem is táplálkoznak az ajánlásoknak megfelelően. A társadalmi értékként jelölt klaszterek esetében megfigyelhető 1-1 egészségesebbnek vélt élelmiszercsoport relatíve magasabb fogyasztása. A negyed klaszterbe tartozók minden élelmiszercsoportból relatíve kevesebbet fogyasztanak, míg az ötödik klaszter esetében a nasi-édesség, valamint divatos termékek fogyasztása a leginkább jellemző.

Kutatásunk során kapott eredmények és tapasztaltak alapján megállapítható, hogy az egyetemi hallgatók a posztadoleszcensek egy szúkebb csoportját jelenti. Bizonyos leválási formák egyértelműen megfigyelhetőek, azonban egyes formák esetében a folyamatban lévőség tapasztalható. Az egészséges táplálkozás, mint társadalmi érték egyértelmúen látható mindabból, hogy az egészségesebbnek vélt élelmiszercsoportokat azokban a klaszterekben fogyasztják nagyobb mértékben, ahol ez a társadalmi főkomponens jelen van.

\section{5. ÖSSZEFOGLALÁS - SUMMARY}

Rohamosan fejlődő világunkban az egészséges életmód egyre nagyobb figyelmet kap. Soha nem lehet elég korán elkezdeni prevenciót és a fokozatos fejlesztést. Kutatásunkban a posztadoleszcensek egészséges, mérsékletes táplálkozási szokásait elemeztük társadalmi aspektusokkal kiegészítve. Kutatásunk során primer és szekunder adatgyüjtést végeztünk. Módszereink között leíró statisztikák, kereszttáblás elemzés, faktoranalízis és klaszteranalízis található. Szociológiai szempontból a leválási dimenziókat vizsgáltuk meg, mellyel megerősítettük, hogy az egyetemi polgárság a posztadoleszcensek egy csoportját képezik. Az egészséges táp- 
lálkozást élelmiszercsoportok és társadalmi vonatkozású faktorok segítségével elemeztünk. A klaszteranalízis során 5 klasztert különítettünk el, amelyeket a faktorokat mentén értékeltünk. A faktor- és klaszteranalízis alapján megállapítottuk, hogy a megkérdezett hallgatók az egészséges táplálkozást fontos társadalmi értéknek tekintik.

\section{KöSZÖNETNYILVÁNíTÁs - ACKNOWLEDGEMENT}

A kutatás a Magyar Tudományos Akadémia Bolyai János kutatási ösztöndíj támogatásával készült.

\section{IRODALOMJEGYZÉK - REFERENCES}

Ács, P. - Hécz, R. - Paár, D. - Stocker, M.: A fittség (m)értéke, A fizikai inaktivitás nemzetgazdasági terhei Magyarországon. Közgazdasági Szemle. 2011. 58 689-708.

Andorka, R.: Bevezetés a szociológiába. Budapest: Osiris Kiadó, 2006.

Arnold, P.: A szülőii háztól való leválás és a drogfogyasztás vizsgálata a fiatal felnőtt populáció körében. In: Arctalan (?) nemzedék, Ifjúság 2000-2010. (Szerk.: Bauer, B. - Szabó, A.) Budapest, Nemzeti Család- és Szociálpolitikai Intézet, 2011. 185-207.

Balatoni, I.: Versenyképesség és egészségkultúra összefüggései regionális megközelítésben. Doktori (PhD) értekezés, Debrecen, Debreceni Egyetem, 2011.

Burn, K. - Szoeke, C.: Boomerang Families and Failure-To-Launch: Commentary on Adult Children Living at Home. Maturitas. 2016. 83 9-12. DOI: https:// doi.org/10.1016/j.maturitas.2015.09.004

Cerin, E. - Barnett, A. - Baranowski, T.: Testing Theories of Dietary Behaviour Change in Youth Using the Mediating Variable Model with Intervention Programs. Journal of Nutrition Education and Behaviour. 2009. 41 309-318. DOI: https://doi.org/10.1016/j. jneb.2009.03.129.
Chen, G. - Jaradat, S. A. - Banerjee, N. Tanaka, T. S. - Ko, M. S. H. - Zhang, M. Q.: Evaluation and Comparison of Clustering Algorithms in Analyzing ES Cell Gene Expression Data. Statistica Sinica. 2002. 12 (1) 241-262.

Cohn, S.: From Health Behaviours to Health Practices, Critical Perspectives. West Sussex: Wiley Blackwell, 2014.

Dudás, K.: Napjaink egyik jellemző trendje, a tudatos fogyasztás értelmezése. Társadalomkutatás. 2011. 29 (3) 315334. DOI: https://doi.org/10.1556/ Tarskut.29.2011.3.3

Dudás, K.: $\quad \mathrm{Az} \quad$ egészségtudatos vásárlói magatartás jellemzői Szakirodalmi összefoglalás. Pécs: Pécsi Tudományegyetem, 2015.

El Ansari, W. - Suominen, S. - Samara, A.: Eating Habits and Dietary Intake: Is Adherence to Dietary Guidelines Associated with Importance of Healthy Eating Among Undergraduate University Students in Finland? Central European Journal of Public Health. 2015. 23 (4) 306-313. DOI: https://doi.org/10.21101/ cejph.a4195

ELEF: A 2014-ben végrehajtott Európai lakossági egészségfelmérés eredményei, Összefoglaló adatok. Központi Statisztikai Hivatal, 2018.

Fitzgerald, A. - Heary, C. - Kelly, C. Nixon, E. -Shevlin, M.: Self-Efficacy for Healthy Eating and Peer Support for Unhealthy Eatingare Associated with Adolescents' Food Intake Patterns. Appetite. 2013. 63 48-58. DOI: https:// doi.org/10.1016/j.appet.2012.12.011.

Fodor, L.: Az egészségmagatartás pszichopedagógiai megközelítése. Magiszter. 2013. (ősz) 14-22.

Hubert, L. - Schultz, J.: Quadratic Assignment as a General Data Analysis Strategy. British Journal of Mathematical and Statistical Psychology. 1976. 29 190-224. DOI: https://doi. org/10.1111/j.2044-8317.1976.tbo0714.x 
Keresztes, N. - Szilágyi, N. - Pálinkás, A. - Rázsó, Zs. - Horváth, G.: Életciklusokon át - Életmódkutatás (pre) serdülő, fiatal felnőtt és felnőtt populációkban. In: Sokszínű sporttudomány. Sportszakmai tanulmányés szakcikk gyüjtemény. (Szerk.: Balogh, L. - Gáldi, G. - Molnár, A. Győri, F. - Alattyáni, I.) László Ferenc Sporttudományi Kutatómúhely (2). Szeged, Szegedi Tudományegyetem Juhász Gyula Pedagógusképző Kar, 2014. 76-88.

KSH: Egészségi állapot és egészségmagatartás, 2016-2017. Statisztikai Tükör. Központi Statisztikai Hivatal, 2018.

MacKay, D.: Chemometrics, Econometrics, Psychometrics-How Best to Handle Hedonics? Food Quality and Preference. 2006. 17 (7) 529-535. DOI: https://doi. org/10.1016/j.foodqual.2005.09.003

Magyar Ifjúság Kutatás: Az ifjúságkutatás első eredményei, ezek a mai magyar fiatalok! Budapest, Új Nemzedék Központ, 2016.

Mahoney, C.: Health, Food and Social Inequality, Critical perspectives on the supply and marketing of food. New York, Routledge. 2015.

Mascherini, M. - Salvatore, L. Meierkord, A. - Jungblut, J-M.: NEETs: young people not in employment, education or training: characteristics, costs and policy responses in Europe. Luxembourg, Publications Office of the European Union, 2012.

Medgyesi, M. - Nagy, I.: Fiatalok életkörülményei Magyarországon és az EU országaiban 2007 és 2012 között. In: Társadalmi Riport 2014. (Szerk.: Kolosi, T. - Tóth, I. Gy.) TÁRKI, Budapest, 2014. $303-323$.

Murinkó, L.: Mitől lesz valaki felnőtt? A családi szerepátmenetek és az önállóvá válás szerepe a felnőttség megítélésében. Demográfia. 2010. 53 (1) 7-37.

NEFI: Egészségjelentés 2015, Információk a hazai egészségveszteségek csökkentéséhez. Budapest: Nemzeti Egészségfejlesztési Intézet, 2015.
Neulinger, Á. - Mitev, A.: Fiatal felnőttek családi rítusai és a felnőtté válás jellemzői a családtól való leválás idején. Szociológiai Szemle. 2017. 27 (1) 64-89.

Pikó, B.: Egészségszociológia. Budapest: Új Mandátum Kiadó, 2002.

Platania, M. - Rapisarda, P. - Rizzo, M.: Food and Health Habits of University Students. Relationship to Food Consumption Behaviour. International Food Research Journal. 2016. 23 (3) 1239-1247.

R Core Team: R: A Language and Environment for Statistical Computing. Vienna: R Foundation for Statistical Computing, 2019.

Sharma, B. - Harker, M. - Harker, D. - Reinhard, K.: Youth Transition to University in Germany and Australia: An Empirical Investigation of Healthy Eating Behaviour. Journal of Youth Studies. 2010. 13 (3) 353-367. DOI: https://doi. org/10.1080/13676260903447510

Somlai, P.: A posztadoleszcensek kora. Bevezetés. In: Új ifjúság. Szociológiai tanulmányok a posztadoleszcensekről. (Szerk.: Somlai, P.) Budapest, Napvilág Kiadó, 2007. 9-44.

Szabó, S.: Egészségorientált táplálkozási szokások és a fogyasztói magatartás kapcsolata. Doktori (PhD) értekezés, Kaposvár, Kaposvári Egyetem, 2016.

Szakály, Z.: Trendek és tendenciák a funkcionális élelmiszerek piacán: Mit vár el a hazai fogyasztó? Élelmiszer, Táplálkozás és Marketing. 2008. 5 (2-3) 3-11.

T. Nagy-Pető, D. - Fehér, A. - Szakály, Z.: Az egészségvédő élelmiszerekkel kapcsolatos fogyasztói attitűdök vizsgálata. Táplálkozásmarketing. 2020. 7 (1) 39-55. DOI: https://doi.org/10.20494/TM/7/1/3

Tercza, G.: A kitolódott fiatalkor a posztadoleszcencia jelensége Magyarországon. Szakdolgozat, Debrecen, Debreceni Egyetem, 2010.

Vaskovics, L.: A posztadoleszcencia szociológia elmélete. Szociológiai Szemle. 2000. 10 (4) 3-20.

Vaskovics, L.: Családszerkezeti átalakulások európai kitekintésben. Szociológiai Szemle. 2014. 24 (1) 5-39. 
Koroknay, Zs. - Pfau, C. - Kovács, S.

Weiss, G. L. - Lonnquist, L. E.: The Sociology of Health, Healing, and Illness.

Eighth Edition. New York, Routledge,

White, K.: An Introduction to the Sociology of Health and Illness. London, SAGE Publications, 2002. 2015 .

\section{JEGYZETEK $\rightsquigarrow$ NOTES}

